\title{
El Estado de las Cooperativas de Consumo: un enfoque de abajo hacia arriba
}

\author{
Macarena Pérez-Suárez ${ }^{1}$ y Juan Antonio Márquez Domínguez ${ }^{2}$
}

Recibido: 14 de octubre de 2017 / Aceptado: 25 de mayo de 2018

Resumen. Este trabajo parte de la duda sobre la continuidad y el futuro de las cooperativas de consumo. Para ello, realiza un análisis estadístico de la evolución de la Economía Social y sitúa, dentro del contexto VICA, a las cooperativas de consumo, con una perspectiva escalar que permite tener una visión territorial de Andalucía, España y Europa. Apoyado en el método científico inductivo (análisis descriptivo), la investigación traza la evolución y la situación actual de las cooperativas de consumo, abriendo un debate sobre el estrenado decrecimiento de estas empresas de Economía Social. Las principales derivaciones señalan una situación crítica y una desvinculación del ámbito local. Sin embargo, fuera del cuantitativismo, en las redes sociales, se observa un fortalecimiento de los valores del cooperativismo de consumo que podría abrir una nueva vía de crecimiento.

Palabras clave: Economía Social; Cooperativas de consumo; Territorio.

Claves Econlit: M21; P13; R12.

\section{[en] The state of consumer co-operatives: a bottom-up approach}

\begin{abstract}
This paper starts from the doubt about the continuity and the future of the consumer cooperatives. To do this, it carries out a statistical analysis of the evolution of the Social Economy and situates, within the VICA context, the consumer cooperatives, with a scalar perspective that allows having a territorial view of Andalusia, Spain and Europe. Based on the scientific inductive method (descriptive analysis), the research describes the evolution and the current situation of the consumer cooperatives, opening a debate about the first decline of these enterprises of Social Economy. The main conclusions show a critical situation and a disconnection from the local scope. However, outside of quantitative, in social networks there is a strengthening of the values of consumer co-operatives that could open a new path of growth.
\end{abstract}

Keywords: Social Economy; Consumer cooperatives; Territory.

Sumario. 1. Introduction. 2. The framework of theory, hypothesis and methodology. 3. Results and Discussion. 4. Conclusions and Implications. 5. References.

Cómo citar: Pérez-Suárez, M. y Márquez Domínguez, J.A. (2018) The state of consumer cooperatives: a bottom-up approach. REVESCO. Revista de Estudios Cooperativos, Segundo Cuatrimestre, $\mathrm{N}^{\circ} 128$, pp. 173-191. DOI: 10.5209/REVE.60734.

1 Universidad de Sevilla, España

Dirección de correo electrónico: mperez32@us.es

2 Universidad de Huelva, España

Dirección de correo electrónico: antonio@uhu.es 


\section{Introduction}

The origins of the Social Economy in Spain date from the late nineteenth and early twentieth century with the cooperative movement, when the first consumer cooperative was founded in 1865 (Medina-Albaladejo and Pujol-Andreu, 2014). Since then, these enterprises are represented by two main interest groups: the consumer partners and the work partners.

On the scientific level, we find an extensive academic work about co-operatives as an economic activity (Chloupkova, 2002, Monzon, 2003, Monzon, 2016) or as a consumer organization (Raccanello, 2012, Medina-Albaladejo and Pujol-Andreu, 2014). Both views reveal critical premises about the evolution of consumer cooperatives in Europe (Brazda and Schediwy, 2003) and some descriptive observations of emerging consumer co-operatives (Delgado et al., 2010). In general, and according to Monzon (2016:10), "for almost 200 years co-operatives are part of the research agenda of the different schools of thought (...) a continuous research thread focused on co-operatives has been developed, much broader and of great intellectual category".

On the other hand, as Marquez (2004) points out, in the mid-1960s consumer co-operatives emerged in Andalusia because of the need for alleviate the high prices of some basic necessities, especially the bread, and to battle the effects of the rural exodus of the 1950s. Thus, the first consumer co-operatives that appeared in the region dedicated their activity to the production and distribution of bakery items, as happened at the end of the fifties in the provinces of Jaen and Huelva. Subsequently, Andalusian consumer co-operatives marketed other household goods. In the 1960s, the region experienced a high moment in the birth of consumer cooperatives, an example of which is the Consumer Cooperative called Virgen de las Mercedes in the town of Bollullos del Condado (Huelva) founded in 1964. After this, consumer co-operatives were not able to establish themselves in the big cities, as it happened on the national level, which, in Andalusia, linked the consumer co-operatives to the rural environment, enhancing the local roots of these organizations. Over time, cooperative associations resulted in the creation in 1990 of the Federation of Andalusian Co-operatives of Consumers and Users. In the last ten years, this entity has been battling the continued disappearance of consumer cooperatives, which must face the great commercial platforms and the weakness of the Andalusian cooperative movement, induced by certain sociological reasons and the crisis of collective values.

At national level, the business model of the consumer cooperative in Spain is defended by Fernando Garrido Tortosa (1821-1883), a disciple of French consumer co-operatives. The ideas of French co-operatives of consumption spread in territories like Catalonia, Valencia and Madrid with the first co-operatives of consumer concealed. The cooperative called Económica Palafrugellense was founded in Girona in 1865 (Sanchis J. and Revuelto L., 1995), as the most emblematic consumer cooperative, among the Spanish pioneers. Certainly, during the first four decades of the twentieth century, consumer co-operatives experienced a boom period, acquiring land on which they built their social premises. After the Civil War, many of these organizations were intervened and damaged by the Cooperatives Act of 1942. Since then, experts have argued that this business fabric 
has not been able to recover in a country characterized by fragmented cooperatives, where consumer co-operatives are ridiculous in big cities. Evidence of this, according to Medina-Albaladejo F.J. and Pujol-Andreu (2014), is the late emergence of intercooperative institutions as well as these only emergences in some regions.

Currently, talk about consumer co-operatives in Spain is talk about the company Eroski because its growth marks the global evolution of the sector in the last decade (Faura, 2002), shows that it is as "in 2003 represented $98 \%$ of Points of sale of Spanish food distribution co-operatives and 95\% of the total points of sale of consumer cooperatives" (Marquez, 2004:39). In the words of Sanchis and Revuelto (1995), the Spanish sector of consumer co-operatives is characterized by a high degree of geographical concentration, among other factors, as a small dimension represented by the scarce presence of large areas and a small number of establishments per society; the low level of investment destined to the expansion and / or diversification; the limited level of management training; and a meager level of commercial equipment. For its part, Marquez (2004) identifies a marked dual configuration in the national profile: a group of large and experienced consumer co-operatives positioned in the local market, and a group of young and small consumer co-operatives in new sectors of activity. This is compounded by the loss of cooperative values and the low participation of consumer partners in corporate bodies.

In the European context, it is curious how "most of the consumer co-operatives prior to 1885 were founded «from above», that is, under the patronage of people from the social elite of the moment" (Brazda and Schediwy, 2003:109). Time has passed and, in general, the European political agenda has given some attention to co-operatives (Monzon, 2016). In the last years, the European Social Economy constitutes, according to Chaves R., Monzon J.L. and Zaragoza (2013:24), "a wide reality, both in human and economic terms (...) the labor force has increased in a sustained way throughout the last decade, from employing $11,000,000$ people in 2002-2003 to 14,500,000 people 7 years later." In this context, according to Faura (2002:16), "the business development of Spanish co-operatives stands out in the European context because it is the one with the greatest growth (...) although the dominance position is much greater in other countries".

At present, in order to know the role and value of cooperative societies within the set of Social Economy on Andalusia and Spain, we show the following general data. The graph shows the evolution of co-operatives constituted in Spain in the period from 2010 to 2014 , in which there is a slight decrease in 2011 , to the explanatory increase in 2012 and thereafter. Thus, we can observe an irregular trend in what is explained by Clemente, Diaz and Marcuello (2008:51). After "to appreciate that the previous literature showed the increasing evolution of both data related to co-operatives (...) this work shows that, as of 2003, there is a change of trend, reducing in the last years of the studied period the number of co-operatives and workers, as well as the items in the profit and loss account. 
Figure. 1. Number of newly created co-operatives in Spain.

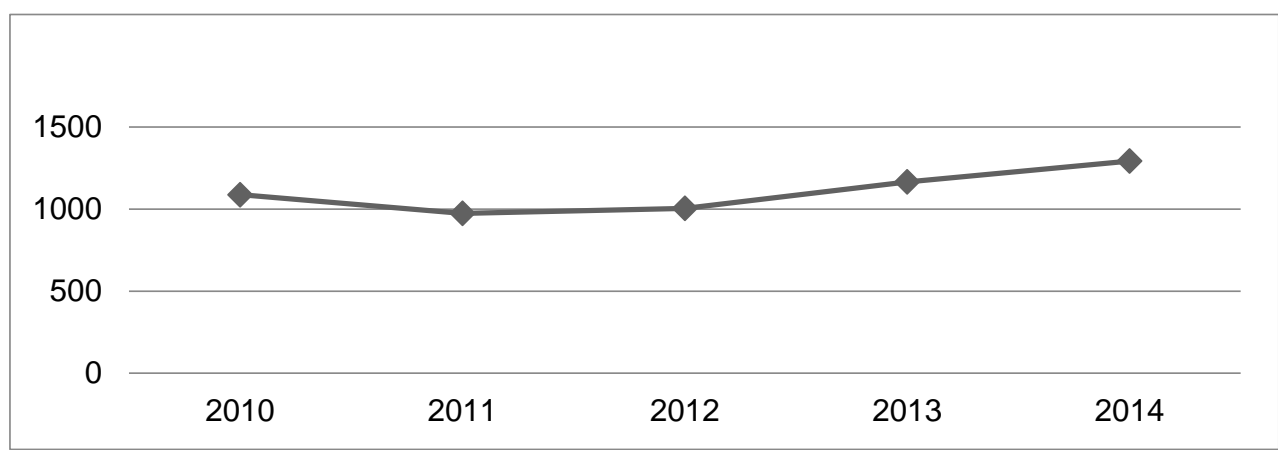

Source: Own elaboration based on data from the Ministry of Employment and Social Security, Social Economy.

Following the analysis of the new co-operatives registered in the period 20102014 in Spain, attention is paid to territorial dissociation. According to the following table, the Andalusian community leads the national ranking followed by the Basque Country and the Valencian Community, while occupying the lowest positions La Rioja and Asturias. It can be seen that in 2012 most of the Autonomous Communities experienced a considerable fall in the number of partners, which may be the cause of the widespread economic crisis and the unquestionable competitiveness of large hypermarkets. At the end of the period analyzed with respect to the beginning, it is observed that the total number of members decreases, while in contrast, the total number of co-operatives is up.

Regarding the number of co-operatives constituted it is noticed that it increases in the majority of autonomous communities, except Catalonia, Navarre, Extremadura and Basque Country that decrease. In the total calculation, and at the end of the period consulted, a positive balance is registered with an increase of 206 incorporated cooperatives.

Table. 1. Constitution Co-operatives by Regions of Spain for the period 2010-2014.

\begin{tabular}{|l|l|l|l|l|l|l|l|l|l|l|}
\hline Regions & \multicolumn{2}{|c|}{2010} & \multicolumn{2}{c|}{2011} & \multicolumn{2}{c|}{2012} & \multicolumn{2}{|c|}{2013} & \multicolumn{2}{c|}{2014} \\
\hline & $\begin{array}{c}\text { No. } \\
\text { Coop. }\end{array}$ & $\begin{array}{c}\text { No. } \\
\text { Members }\end{array}$ & $\begin{array}{c}\text { No. } \\
\text { Coop. }\end{array}$ & $\begin{array}{c}\text { No. } \\
\text { Members }\end{array}$ & $\begin{array}{c}\text { No. } \\
\text { Coop. }\end{array}$ & $\begin{array}{c}\text { No. } \\
\text { Members }\end{array}$ & $\begin{array}{c}\text { No. } \\
\text { Coop. }\end{array}$ & $\begin{array}{c}\text { No. } \\
\text { Members }\end{array}$ & $\begin{array}{c}\text { No. } \\
\text { Coop. }\end{array}$ & $\begin{array}{c}\text { No. } \\
\text { Members }\end{array}$ \\
\hline Andalucía & 173 & 902 & 154 & 1395 & 168 & 781 & 230 & 939 & 284 & 1164 \\
\hline Aragón & 45 & 299 & 59 & 305 & 32 & 118 & 28 & 379 & 37 & 163 \\
\hline Asturias & 7 & 30 & 10 & 62 & 5 & 17 & 14 & 114 & 14 & 55 \\
\hline Baleares & 17 & 112 & 15 & 179 & 6 & 34 & 17 & 107 & 17 & 75 \\
\hline Canarias & 11 & 80 & 14 & 47 & 3 & 16 & 10 & 39 & 19 & 84 \\
\hline Cantabria & 2 & 27 & 5 & 15 & 4 & 28 & 7 & 39 & 16 & 53 \\
\hline $\begin{array}{l}\text { Castilla- } \\
\text { Mancha }\end{array}$ & 16 & 106 & 5 & 16 & 20 & 127 & 25 & 2327 & 32 & 123 \\
\hline Castilla- & 52 & 5501 & 31 & 347 & 35 & 178 & 28 & 123 & 36 & 149 \\
\hline
\end{tabular}




\begin{tabular}{|l|l|l|l|l|l|l|l|l|l|l|}
\hline León & & & & & & & & & & \\
\hline Cataluña & 115 & 490 & 113 & 1598 & 147 & 644 & 148 & 599 & 118 & 1189 \\
\hline C.Valenciana & 104 & 480 & 93 & 369 & 97 & 357 & 123 & 434 & 132 & 391 \\
\hline Extremadura & 17 & 102 & 19 & 121 & 22 & 195 & 33 & 78 & 29 & 287 \\
\hline Galicia & 41 & 1534 & 47 & 851 & 51 & 515 & 60 & 417 & 69 & 501 \\
\hline Madrid & 135 & 1081 & 109 & 684 & 83 & 637 & 86 & 412 & 108 & 710 \\
\hline Murcia & 137 & 504 & 82 & 321 & 80 & 341 & 86 & 287 & 132 & 424 \\
\hline Navarra & 18 & 143 & 16 & 224 & 16 & 135 & 33 & 142 & 23 & 100 \\
\hline P. Vasco & 161 & 659 & 150 & 639 & 200 & 1621 & 196 & 805 & 193 & 717 \\
\hline Rioja & 11 & 41 & 13 & 80 & 11 & 98 & 9 & 70 & 9 & 25 \\
\hline
\end{tabular}

Source: Own elaboration based on data from the Ministry of Employment and Social Security, Social Economy.

The following graph shows the Spanish autonomous communities with the highest number of co-operatives registered in the period from 2010 to 2014. The most dynamic regions in the creation of cooperative societies are Andalusia, the Basque Country, Catalonia, Valencia and Madrid. The contribution of each of the regions is reflected; at the same time that we notice that the contribution of Andalusia in the national set is remarkable.

Figure. 2. Autonomous regions with the highest number of co-operatives registered in the period 2010-2014.

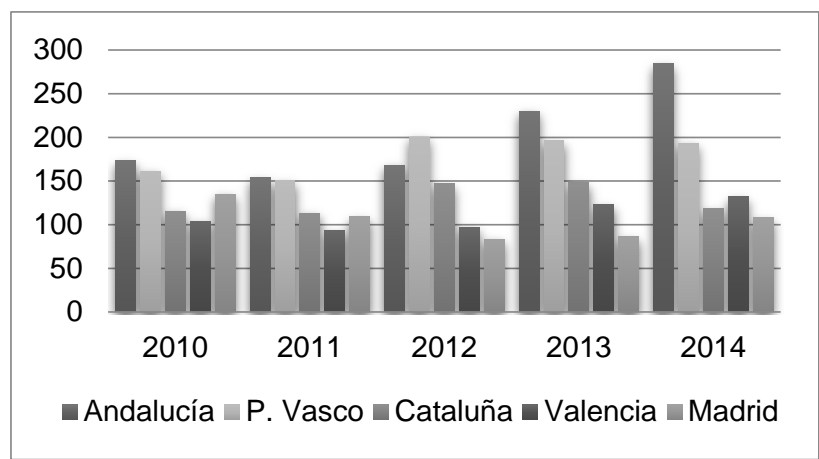

Source: Own elaboration based on data from the Ministry of Employment and Social Security, Social Economy.

In Andalusia, the province of Seville stands out as it leads the sector in terms of co-operatives registered from 2010 to 2013, being surpassed in 2014 by the province of Malaga, which occupies the second position during the period under 
analysis. The progress, in general, indicates an increase in the number of cooperatives in the Andalusian community. According to the number of registered members, Seville is the province with the largest number of partners, followed, again, Malaga and Granada, as a whole the trend is increasing. A fact that stands out, even more, in the period of crisis that Cardenete et al. (2017:52) said the crisis has not meant improving the position of the andalusian economy.

When conducting a comparative analysis between Spain and Andalusia in the period 2010-2014, the leadership of the Andalusian cooperative is observed, since Andalusia has about 4000 cooperative societies of which approximately $80 \%$ are labor co-operatives that give direct employment to more of 59000 people. While in Spain the co-operatives are formed by around 22000 companies that employ 300000 people.

In relation to the economic importance of the Social Economy, Chaves, Monzon and Zaragoza (2013:22) point out that Spain is the first country to approve a Law of Social Economy and that "the gross added value of the whole Social Economy in relation to GDP was in 2008 of 2.47 percent, providing direct employment to $1,243,596$ people in 200858 entities."

Recently, Official Sources of the Public Administration-Ministry of Employment and Social Security indicated that the sector in Spain is linked to the economic recovery, with a weight that represents $10 \%$ of $\mathrm{GDP}^{3}$ and whose number of jobs agglutinates More than 2 million people ${ }^{4}$. The importance of the cooperative movement is confirmed by Monzon (2016), who from data from the $\mathrm{EPA}^{5}$ and the Ministry of Labor, states that in the harder periods of the crisis, from 2009 to 2013 , the employment fell $18,5 \%$ in private sector, while in the cooperative sector was $8 \%$, ten points less ${ }^{6}$. One measure linked to this result is the current Program of Promotion and Promotion of the Social Economy 2015-2016 of Spain, whose objective is to develop the sector based on four axes: Creation and strengthening of Social Economy entities through new instruments of Financial support for membership; Review and update of the legal framework - greater legal security-; Support for internationalization and innovation and the Operational Program for Social Inclusion and the Social Economy endowed with almost 1.1 billion Euros in total investment from the European Social Fund.

\footnotetext{
Source: http://www.cepes.es/social/estadisticas

Source: http://www.empleo.gob.es/es/sec_trabajo/autonomos/economia-soc/noticias/ Source: Encuesta de Población Activa (EPA) http://www.ine.es/prensa/epa_tabla.htm Source: http://elpais.com/elpais/2016/09/02/media/1472834142_462203.html
} 
Figure. 3. Evolution of the Number of Cooperative Societies in Andalusia and in the rest of Spain.

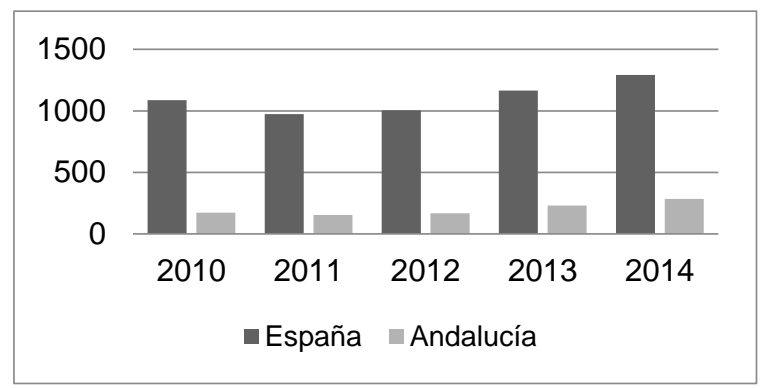

Spain

Source: Own elaboration based on data from the Ministry of Employment and Social Security, Social Economy.

In Andalusia, in relation to the impulse of consumer cooperatives, the Andalusian Federation of Consumer and User Co-operatives -FEDECCON- is operating, which is a non-profit organization that groups 63 Co-operatives of Consumption.

Fedeccon groups together around 50,000 consumer partners and invoices more than 120 million Euros, mainly in the food distribution and planning sectors. At the national level, HISPACOP, the Spanish Confederation of Consumer and User Cooperatives, groups a total of 128 consumer co-operatives representing more than 2,800,000 consumer partners, more than 59,000 workers and a turnover of more than 10.2 billion Euros ${ }^{7}$. Thirdly, at European level, the EURO COOP ${ }^{8}$, created in 1957, groups together 28 European organizations representing 75 million members -Germany, Belgium, Denmark, France, Holland, England, Italy and Luxembourgwith an annual turnover of 50 Billions of Euros. Again, an expert on the benefits of the cooperative model explained "that consumer co-operatives are more active than ever, working and collaborating through e-commerce" $"$.

Today, another example of the key role of this economic sector is the resolution adopted by European Parliament on 19 January 2017 as "a European pillar of social rights", in which it is considered essential that companies have a responsible behavior like social enterprises because, "they provide a good example when creating quality employment, support social inclusion and promote a participatory economy (...) make the labor market more inclusive, and support the Use of social criteria in public procurement". According to Diaz and Marcuello (2012:155),

\footnotetext{
Source: http://www.consumoresponde.es/art\%C3\%ADculos/las_cooperativas_de_consumo

Source: http://www.eurocoop.coop/

Source: http://monitor.coop/es/media/news/noticias-de-los-sectores-las-cooperativas-de-consumo
} 
social enterprises "are formed to meet the needs of a particular group of members through business activities. Thus, the promoters would be a group of citizens and the activities carried out would be productive and commercial activities aimed at providing specific goods and services: energy, finance, food... Among the organizational models that would be included in this model would be some consumer cooperatives, credit cooperatives, worker co-operatives or associations". From these words, it is clear that cooperatives, particularly consumer cooperatives, are not considered social enterprises. Although, on the other hand, "concrete examples are currently appearing that develop in a practical way the social markets (...) spaces where the different paths that share responsible consumption as a fundamental objective in their organic development converge and that wish to carry out a shared work, managed under criteria of cooperative of services" (Diaz and Marcuello, 2012: 160-161). As well as, the term "Social Economy" notorious in the European Union "results from a broad conception of the third sector that includes mainly cooperatives, mutual societies, associations, foundations and other socially oriented enterprises" (Chaves and Zimmer, 2017:4). No doubt, a partial nuance so far.

However, the Social Economy sector must face a number of challenges. According to Monzon (2012:16), the global economy poses challenges of a double nature to co-operatives: first, "from a microeconomic and entrepreneurial perspective, co-operatives need to develop competitive strategies that allow them to generate competitive advantages", second "From an institutional perspective, social utility, the social added value of cooperatives, can only be maintained to the extent that they are able to preserve cooperative values and principles in their behavior." This premise is shared by Raccanello (2012:5) when he states that "the permanent challenge imposed on consumer cooperatives, and the cooperative movement, is their integrity."

In a VICA context -of volatility, uncertainty, complexity, ambiguity- research on consumer co-operatives aims, from theory, to establish a hypothesis, methodology and results. This theoretical framework is supported by a more detailed analysis in Andalusia, Spain and Europe, which allows drawing conclusions and socioeconomic implications for a debate on the future of consumer cooperatives.

\section{The framework of theory, hypothesis and methodology}

The content of this work is based on the topic of study: «consumer cooperatives», on the basis of which, immediately, the references examined are collected. However, it should be noted that several authors link the "life cycle theory of the cooperative enterprise" directly with the development process of consumer cooperatives (Brazda and Schediwy, 2003; Medina-Albaladejo and Pujol-Andreu, 2014). As well, the topic of study is directly linked to social networks with reference to the exchange of use value and even social values (Pérez and Carrillo, 2000; Alburquerque, 2006).

A consumer cooperative is defined as an entity that "distributes goods and services for personal and household use and consumption to its members under satisfactory conditions of price, quality, measure or opportunity" (Kaplan de 
Drimer and Drimer, 1975:198). This definition is marked by two particularities: the marked tendency to "carry out important processes of rationalization, concentration and coordination of its activities" (Kaplan de Drimer and Drimer, 1975:201) and the change of paradigm in the "first decade of the 21st century, the processes of concentration, at multinational level, led to the gradual elimination of the productive and associative forms deeply rooted in history and in the territory (...) it follows that the objective of these aim of making the consumer a major player in the market implies a long-term vision" (Kaplan de Drimer and Drimer, 1975:204).

Table. 2. Review of Literature.

\begin{tabular}{|c|l|l|}
\hline Time & Authors & \multicolumn{1}{|c|}{ The Main Premises } \\
\hline $\mathbf{1 9 7 8}$ & Saez & $\begin{array}{l}\text { The future is more prosperous to co-operatives than to other types } \\
\text { of movements. }\end{array}$ \\
\hline $\mathbf{1 9 9 5}$ & $\begin{array}{l}\text { Sanchis \& } \\
\text { Revuelto }\end{array}$ & $\begin{array}{l}\text { The development of consumer co-operatives has been } \\
\text { heterogeneous in Europe. There is no homogeneous cooperative } \\
\text { movement in integration processes. }\end{array}$ \\
\hline $\mathbf{2 0 0 3}$ & $\begin{array}{l}\text { Revuelto \& } \\
\text { Marche }\end{array}$ & $\begin{array}{l}\text { In the case of retail trade, the Life Cycle Theory of the cooperative } \\
\text { enterprise is exposed. }\end{array}$ \\
\hline Schediwy \& $\&$ & $\begin{array}{l}\text { During the twentieth century, the cooperative consumption } \\
\text { movement has disappeared for economic reasons and deteriorated } \\
\text { classic consumption. Companies have a tendency to reduce the } \\
\text { "associations" aspect in favor of business profit for several reasons: } \\
\text { increasing competition in the retail sector; The obstacles to the } \\
\text { traditional distribution of the dividend; The lack of attention to the } \\
\text { first sectored losses; The direct linkage to the traditional culture of } \\
\text { the labor movement; Organizational tensions; Unfair competition } \\
\text { in the sector; And the fatigue of partners and representatives. }\end{array}$ \\
\hline Monzon & $\begin{array}{l}\text { Consumer co-operatives group their members as "users" of goods } \\
\text { and / or services supplied by the company they constitute for this } \\
\text { purpose. }\end{array}$ \\
\hline 2012 & $\begin{array}{l}\text { Campos- } \\
\text { Climent \& } \\
\text { Sanchis }\end{array}$ & $\begin{array}{l}\text { Consumer co-operatives can be positioned in a market segment } \\
\text { characterized by the supply of products originating from } \\
\text { cooperative production companies, products with a designation of } \\
\text { origin, indigenous and with a marked ecological or natural } \\
\text { character. }\end{array}$ \\
\hline Raccanello & $\begin{array}{l}\text { Consumer co-operatives have weakened its ability to commend the } \\
\text { entrepreneurship and associations. } \\
\text { Consumer co-operatives have deteriorated over time. } \\
\text { The efficient consumer cooperative will maximize the "net } \\
\text { consumer surplus" (Enke's Howarth Principle (1945), which } \\
\text { responds to the surplus distributed among partners in proportion to } \\
\text { their purchases). }\end{array}$ \\
$\begin{array}{l}\text { Corporate communication and structured dialogue with its } \\
\text { stakeholders are an integral and key part of the management of any } \\
\text { consumer cooperative. }\end{array}$ \\
\hline
\end{tabular}




\begin{tabular}{|l|l|l|}
\hline 2014 & $\begin{array}{l}\text { Etxezarreta } \\
\text { \& Merino }\end{array}$ & $\begin{array}{l}\text { Consumer cooperative societies must mediate in society from } \\
\text { public opinion and cooperation with institutions for their character } \\
\text { as a consumer structure, a structure in which the members' } \\
\text { commitment and experiential knowledge of social benefit interact. }\end{array}$ \\
\cline { 2 - 4 } $\mathbf{2 0 1 7}$ & $\begin{array}{l}\text { Cabanes \& } \\
\text { Gomez }\end{array}$ & $\begin{array}{l}\text { The experiences of agroecological co-operatives (production and } \\
\text { consumption), mostly, occur in impoverished areas, and use the } \\
\text { collective socio-economic structure as a tool to transform reality. }\end{array}$ \\
\hline Vargas \& & $\begin{array}{l}\text { The existence of manager-partner in consumer co-operatives is } \\
\text { frequent, being this position and its formation a strategic line. }\end{array}$ \\
\hline
\end{tabular}

Source: Own elaboration.

There is an irregularity in the scientific treatment of the topic "consumer cooperatives". The scattered references indicate a treatment without relevance, may be derived from the progress of the research topic "Social Economy". In particular, in Spain there are old references to certain business cases such as Eroski, Abacus and San Francisco de Asís in the 1990s. After the examination, it is also expressed as the topic of study takes national scope (Maixé-Altés, 2009; Watts, 2017) and European (Chloupkova, 2002) to the detriment of the regional one (Marquez, 2004). Definitely, the set of literature consulted leads to the hypothesis of the research:

H1. The behavior of consumer co-operatives is weakened or maintained over time and, in the case of registering subsistence, it is linked to the social networks of the territories

The methodology has been strict. Data collection was done through primary sources - Ministry of Employment and Social Security of Spain; National Institute of Statistics (INE) and secondary sources (Quintana, 2016) during the period 20152017. The data were introduced and handled in Excel, from which the necessary and precise information was generated to contrast the hypothesis formulated. As a method, the descriptive statistic was chosen from frequencies and contingency tables.

\section{Results and discussion}

\subsection{Consumer Co-operatives in Andalusia}

The following table shows the number of co-operatives constituted by economic activity in Andalusia in the period 2010-2014. 
Table. 3. Number of co-operatives constituted in Andalusia according to typology in the period 2010-2014.

\begin{tabular}{|c|c|c|c|c|c|c|c|c|}
\hline Year & $\begin{array}{c}\text { Co- } \\
\text { operatives of } \\
\text { Associated } \\
\text { Work }\end{array}$ & Agricultural & Housing & Others & Services & Transport & Consumer & $\begin{array}{c}\text { Explot Co- } \\
\text { operatives. } \\
\text { Com. Earth }\end{array}$ \\
\hline 2010 & 128 & 16 & 14 & 6 & 4 & 0 & 2 & 3 \\
\hline 2011 & 116 & 10 & 20 & 4 & 1 & 0 & 3 & 0 \\
\hline 2012 & 140 & 14 & 1 & 2 & 8 & 0 & 3 & 0 \\
\hline 2013 & 204 & 7 & 4 & 2 & 6 & 3 & 3 & 1 \\
\hline 2014 & 233 & 15 & 13 & 13 & 5 & 2 & 3 & 0 \\
\hline
\end{tabular}

Source: Own elaboration based on data from the Ministry of Employment and Social Security, Social Economy.

It can be observed that, in the region, the co-operatives of associated work occupy a significant weight, while the consumer co-operatives present an inconsequential position within the categorical reality.

In order to confirm the above, Andalusian cooperative societies are approached in the year 2015 according to the number of companies and number of workers in the various modalities of this legal form, whose total is of 2743 companies and 56489 workers. It is verified that the consumer co-operatives (46 companies) do not stand out in the social business fabric of Andalusia, because the weight is captured by co-operatives of associated work and agricultural co-operatives according to the number of companies with economic activity.

Table. 4. Number of Co-operatives and Number of workers by type in 2015.

\begin{tabular}{|c|c|c|c|c|c|c|c|c|c|c|c|}
\hline \multicolumn{2}{|c|}{$\begin{array}{l}\text { Co-operatives of } \\
\text { Associated Work }\end{array}$} & \multicolumn{2}{|c|}{$\begin{array}{c}\text { Consumer } \\
\text { Co-operatives }\end{array}$} & \multicolumn{2}{|c|}{ Housing } & \multicolumn{2}{|c|}{ Agricultural } & \multicolumn{2}{|c|}{$\begin{array}{c}\text { Explot } \\
\text { Cooperatives. } \\
\text { Com. Earth }\end{array}$} & \multicolumn{2}{|c|}{ Services } \\
\hline $\begin{array}{l}\text { No. } \\
\text { Coop. }\end{array}$ & $\begin{array}{c}\text { No. } \\
\text { Members }\end{array}$ & $\begin{array}{c}\text { No. } \\
\text { Coop }\end{array}$ & $\begin{array}{c}\text { No. } \\
\text { Members }\end{array}$ & $\begin{array}{c}\text { No. } \\
\text { Coop }\end{array}$ & $\begin{array}{c}\text { No. } \\
\text { Members }\end{array}$ & $\begin{array}{l}\text { No. } \\
\text { Coop }\end{array}$ & $\begin{array}{c}\text { No. } \\
\text { Members }\end{array}$ & $\begin{array}{c}\text { No. } \\
\text { Coop }\end{array}$ & $\begin{array}{c}\text { No. } \\
\text { Members }\end{array}$ & $\begin{array}{l}\text { No. } \\
\text { Coop }\end{array}$ & $\begin{array}{c}\text { No. } \\
\text { Members }\end{array}$ \\
\hline 1.733 & 23.104 & 46 & 353 & 3 & 61 & 719 & 19.369 & 61 & 848 & 93 & 4.104 \\
\hline \multicolumn{2}{|c|}{ Transport } & \multicolumn{2}{|c|}{ Health } & \multicolumn{2}{|c|}{ Teaching } & \multicolumn{2}{|c|}{ Credit Unions } & \multicolumn{2}{|c|}{ Others } & \multicolumn{2}{|c|}{ Unclassified } \\
\hline $\begin{array}{c}\text { No. } \\
\text { Coop. }\end{array}$ & $\begin{array}{c}\text { No. } \\
\text { Members }\end{array}$ & $\begin{array}{c}\text { No. } \\
\text { Coop. }\end{array}$ & $\begin{array}{c}\text { No. } \\
\text { Members }\end{array}$ & $\begin{array}{c}\text { No. } \\
\text { Coop. }\end{array}$ & $\begin{array}{c}\text { No. } \\
\text { Members }\end{array}$ & $\begin{array}{c}\text { No. } \\
\text { Coop. }\end{array}$ & $\begin{array}{c}\text { No. } \\
\text { Members }\end{array}$ & $\begin{array}{c}\text { No. } \\
\text { Coop. }\end{array}$ & $\begin{array}{c}\text { No. } \\
\text { Members }\end{array}$ & $\begin{array}{c}\text { No. } \\
\text { Coop. }\end{array}$ & $\begin{array}{c}\text { No. } \\
\text { Members }\end{array}$ \\
\hline 24 & 108 & 0 & 0 & 2 & 55 & 9 & 7.828 & 44 & 637 & 9 & 22 \\
\hline
\end{tabular}

Source: Own elaboration based on data from the Ministry of Employment and Social Security, Social Economy. 
A few years ago, an expert in consumer co-operatives in Spain (Ignasi Faura) stated that in Andalusia there was a double struggle in consumer cooperatives: adjustment of the business group and the diversity of the offer in face of the new needs, services, People, types of consumption, etc. The structure of consumer cooperatives in the region is based on local reality. The truth is that for him, the balance of this experience in Andalusia has not yet been experienced; therefore, it is difficult to make a precise assessment.

Marquez (2004) points out that in 2003 Andalusian consumer co-operatives were 63 companies while nationwide when they were to 327 companies. The main indicator is that already the cooperative universe of consumption was based on the co-operatives of associated work, continued from agricultural cooperatives. Fourteen years later, cited distribution has not changed in Andalusia. As the author points out, it may be that the origin lies in the fact that most Spanish consumer cooperatives are at a level of weak sensitivity (dedication to trade in products); Or as it marks the map of the Andalusian consumer co-operatives over the total, these societies are scattered, coinciding in space with the general cooperative phenomenon

In recognition of the local roots and the decline of the consumer co-operatives movement, the urban areas with the greatest commercial and economic dynamism are harsh for these co-operatives in their current format, being relegated to the most distant spaces, between depopulated surroundings and the cities. Marquez (2004: 140) argues that, for the moment, consumer cooperative societies resist in the market "through the price struggle and the traditional system that they have always used to capture the near market (...) they have an intangible capital that is not very valued by its own cooperative entity: the sentimental and territorial capital. A cooperative is born for a territory and can only survive as long as it relates to and with that territory."

In Andalusia, according to the autonomous federation of consumer cooperatives, there were about 100 companies in the nineties. The temporary decrease registered is due to several external factors: "the increase of the purchasing power of the rural environment; The eruption in the rural world of the large distribution chains (supermarkets); Changes in consumption habits; The limited ability to adapt to the new rules of the game "(Marquez, 2004:144). And to other inner, such as "the aging of the partners, the inability to attract the young population, lack of cooperative management" (Marquez, 2004:146).

Lastly, it can be observed that in the region of Andalusia the consumer cooperatives fall in the course of time, being not significant their representation in the cooperative group of the territory. Based on the localized empirical demonstrations in the matter, everything seems to indicate that this type of social enterprise will disappear in Andalucia in the face of growing local uprooting.

\subsection{Consumer Co-operatives in Spain}

In 2016, in Spain, the cooperative sector grouped a total of 20,792 companies, whose main location, once again, resides in Andalusia with 3,994 cooperatives.

Given the present situation of Spanish cooperatives, in general terms and in relation to the topic of research, it can be said that at this moment the weight of 
consumer co-operatives according to the national total is less than $10 \%$. That is, cooperatives of Consumption have an insignificant position within the national set.

It is observed how in Spain the consumer co-operatives fall in the course of time, being not significant their representation in the cooperative group as already illustrated. Accordingly, the total turnover of all these enterprises is decreasing successively.

Figure. 6. Total of Consumer Co-operatives in Spain.

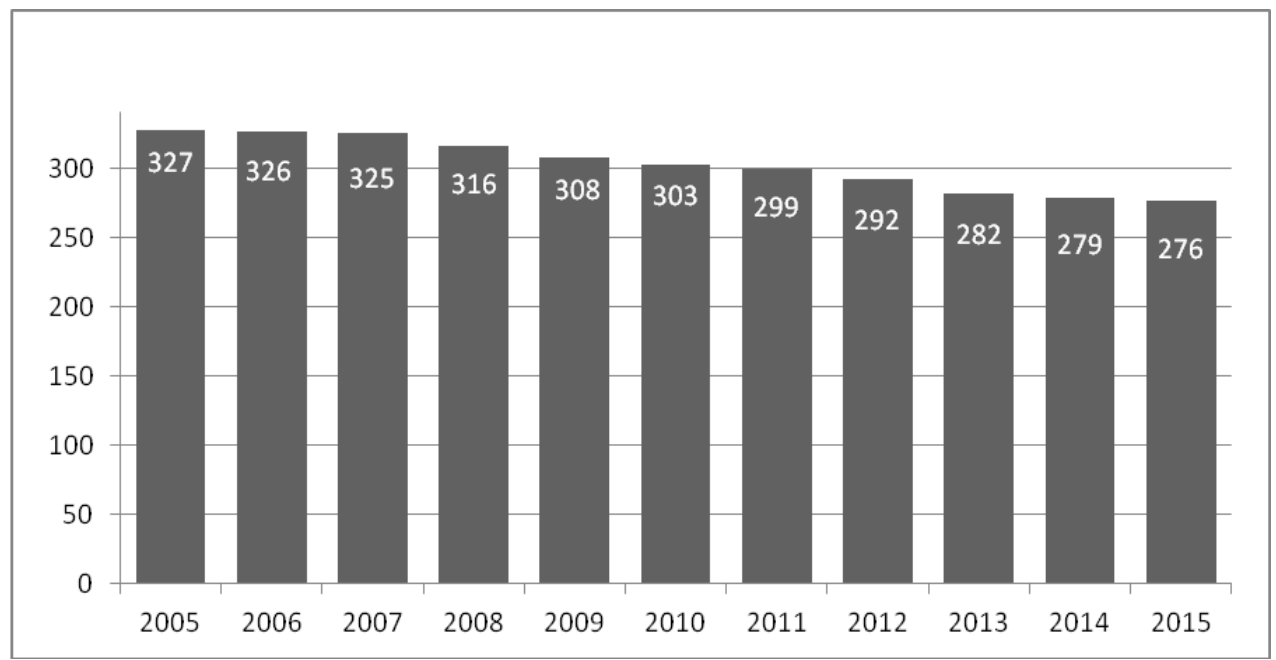

Source: INE.

Figure. 7. Total Billing of the Consumer Co-operatives of Spain.

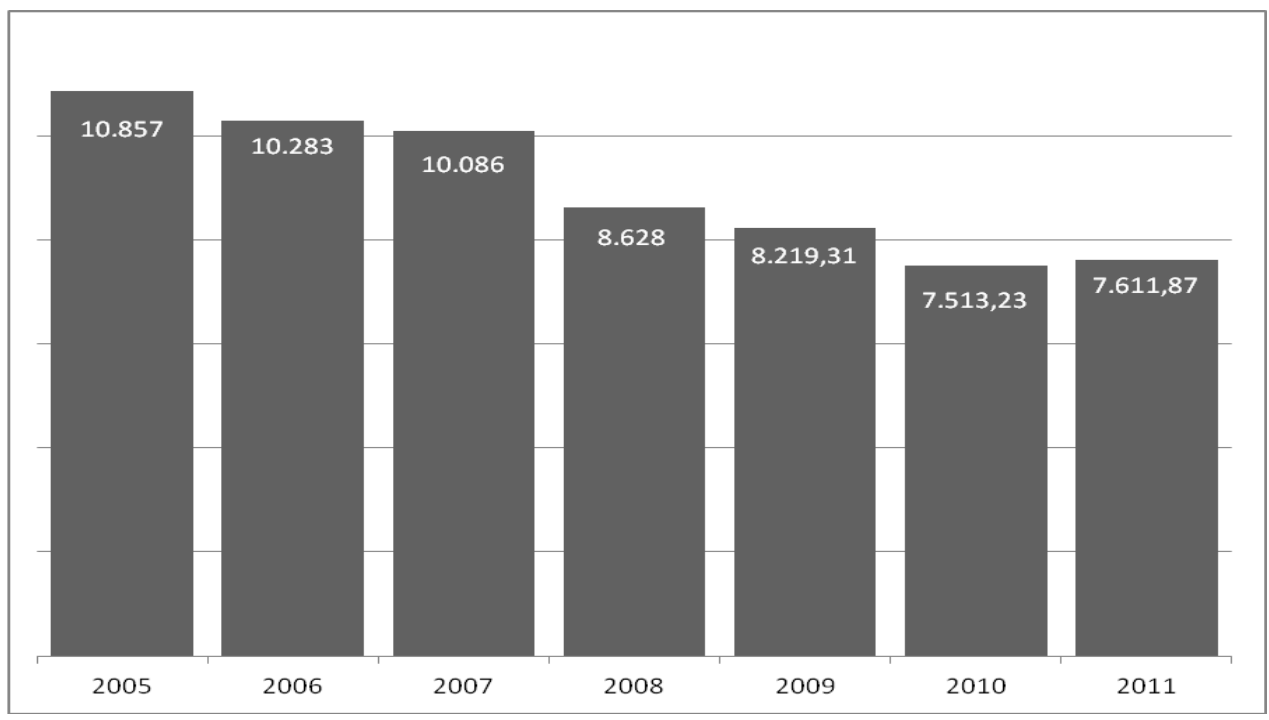

Source: INE. 
Finally, it is shown how in Spain the consumer co-operatives fall in the course of time, being not significant their representation in the cooperative group of the territory. Based on the localized empirical demonstrations in the matter, everything seems to indicate that this type of enterprise will disappear in Spain in front of the hegemony of other types of Social Economy's enterprises. Or perhaps clustered territorially minority groups find the continuation.

\subsection{Consumer Co-operatives in Europe}

In Europe, there were more than 6,000 consumer co-operatives companies with an annual turnover of over 50 billion Euros in 2015 (Quintana, 2016). It is observed a business group concentrated at a territorial level in a number of countries: Italy, Romania, Hungary, Bulgaria, United Kingdom, Germany, Poland and Spain. That is, there are Member States with a corporate fabric of consumer co-operatives and there are Member States in which this type of social enterprise is not recognized or registered in a subdued way. It is a reality of extreme manifestations. In addition, it can be seen that the Spanish fabric of consumer co-operatives is similar in weight to other European countries such as Poland, Germany and the United Kingdom, when the United Kingdom is the birthplace of consumer co-operatives (Kaplan de Drimer and Drimer, 1975:268).

Figure. 8. Total European Consumer Co-operatives in 2015.

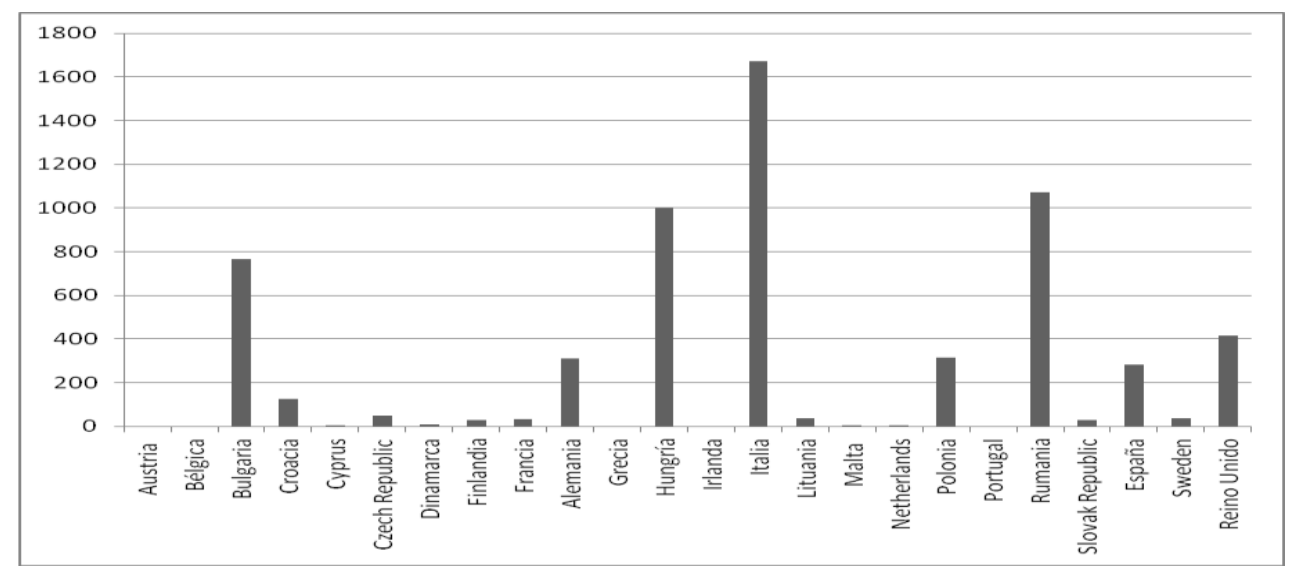

Source: Own elaboration based on data from EURO COOP in Quintana (2016).

On the other hand, and again in 2015, according to the main European consumer co-operatives and a total turnover of more than 50 billion Euros, they occupy the top positions: Italy, Finland, United Kingdom and Spain. A fourth position that perceives a set of business explanatory economic results. 
Figure. 9. Total Billing of the Ranking of Consumer Co-operatives in Europe.

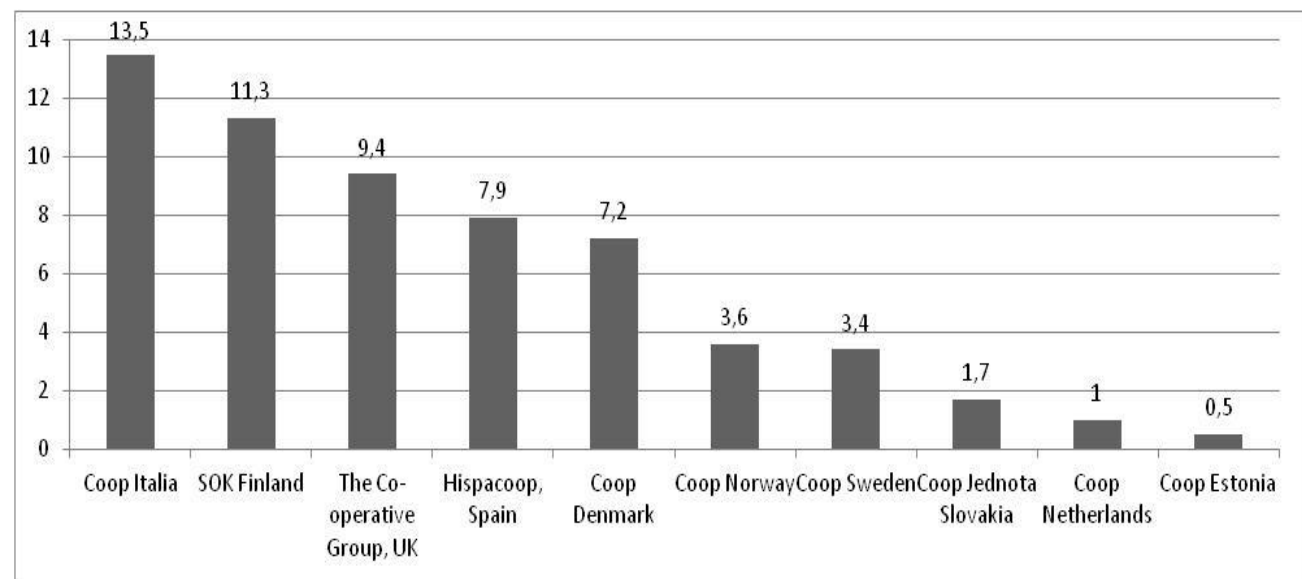

Source: Own elaboration based on data from EURO COOP in Quintana C. (2016).

According to the turnover of consumer co-operatives in Europe, the behavior is irregular because there is no sequence in it. However, it seems that over time these enterprises obtain higher economic results.

Table. 5. Variation rate of the Total Billing of the Consumer Co-operatives of Europe with base year for 2008 .

\begin{tabular}{|l|r|r|r|}
\hline Country & Annual Variation Rate of Billing Volume (€ million) \\
\hline Bulgaria & $\mathbf{2 0 0 9}$ & $\mathbf{2 0 1 0}$ & \multicolumn{1}{c|}{$\mathbf{2 0 1 1}$} \\
\hline Cyprus & $-3,91 \%$ & $4,07 \%$ & $66,41 \%$ \\
\hline Czech Republic & $-1,89 \%$ & $-19,23 \%$ & $-99,12 \%$ \\
\hline Denmark & $0,00 \%$ & $-100,00 \%$ & $100,00 \%$ \\
\hline Finland & $-0,04 \%$ & $4,68 \%$ & $13,79 \%$ \\
\hline Germany & $-10,46 \%$ & $9,52 \%$ & $1,65 \%$ \\
\hline Hungary & $0,00 \%$ & $100,00 \%$ & $58,73 \%$ \\
\hline Italy & $1,76 \%$ & $0,00 \%$ & $-38,95 \%$ \\
\hline Holland & $1,21 \%$ & $1,88 \%$ & $1035,62 \%$ \\
\hline Romania & $0,64 \%$ & $-5,73 \%$ & $1260,81 \%$ \\
\hline Slovak Republic & $-3,09 \%$ & $-10,64 \%$ & $-100,00 \%$ \\
\hline Spain & $521,83 \%$ & $-6,45 \%$ & $973,30 \%$ \\
\hline Sweden & $-1,91 \%$ & $-14,46 \%$ & $44,99 \%$ \\
\hline United Kingdom & $32,12 \%$ & $-14,35 \%$ & $9,34 \%$ \\
\hline
\end{tabular}

Source: Own elaboration based on data from EURO COOP in Quintana C. (2016). 
In summary, in Europe consumer co-operatives are active on a regular basis over time. On the basis of the empirical demonstrations shown, it seems that this type of social enterprise will disappear in some European countries, while concentrating on another minority group.

\section{Conclusions and implications}

The empirical conclusions are diverse. The main contribution has been to present, through a scaled-up approach, the real and territorial state of the business fabric of consumer cooperatives. In this sense, research constitutes an advance in the still scarce empirical research on certain Social Economy's enterprises, the consumer cooperatives.

The results obtained confirm the hypothesis put forward. That is, when the evolution and the low significance of the consumer co-operatives intuited its disappearance, in a context of crisis, the consumer co-operatives have been maintained and their alternative values to capitalist enterprises are being driven in social networks.

In addition, the behavior of consumer co-operatives responds to an upward reply at the territorial level, a behavior that presents similarities from the local to the global. In particular, there is a current territorial analogy in the case of Spain and in the case of Andalusia, because in both cases the consumer co-operatives disappear over time and, within the total of active co-operatives in each territory, the consumer co-operatives are not relevant in any case.

About the quantitative treatment of the evolution of the cooperative societies in the period 2010-2014, of Spain and Andalusia, we emphasize that the cooperative company in Spain registers growth. This fact is significant in a situation of full crisis, especially in the Andalusian community that co-operatives have a relevant role within the Social Economy. Although the official data sources present clear limitations (Calderon and Calderon, 2012:31), the analysis carried out is a starting point, with a more developed statistical analysis research with an expanded hypothesis contrast.

It is shared with Medina-Albaladejo and Pujol-Andreu (2014:24) that from "our research, although still very general, several hypotheses emerge. The first is that consumer co-operatives in Spain had less impact than in other societies in Western Europe (...) because of the scarce attention paid by public institutions to such associations, of the country's poor industrial development, and of the deep division of the cooperative movement in different ideological groups, little related among them. The second hypothesis is that consumer co-operatives contributed significantly to the nutritional transition in two ways: they facilitated more stable and quality access to staple foods and helped spread more diversified diets with the commercialization of new products".

As Kaplan de Drimer and Drimer (1975:72) visionarily pointed out, "consumer co-operatives must develop indefinitely to encompass the entire economic-social organization".

This work can have positive repercussions, since it raises the evolution of consumer co-operatives as an alternative strategy to the purely business system and 
also bets on the values of cooperative associations and its relation to the territories (Faura and Udina, 2004).

All this has not gone unnoticed in the European Union, which is betting on the Social Economy, with special attention to the cooperative environment in the European Commission's 2020 Strategy (Monzon and Chaves, 2012). For the academic field, new horizons are opened up because to this descriptive investigation of global and current scope it can be added other concerns and more detailed investigations on the prices of purchase and sale, the socioeconomic characteristics of the associates and leaders of the consumer cooperatives, or the linking of these enterprises to the nascent collaborative consumption (real sharing movement ${ }^{10}$ ) and / or Startups. In addition, case studies such as the Co-op Food (USA) a food cooperative whose 16,000 members work 3 hours a month to have the right to buy the best food in New York City at the lowest possible price in the midst of the economic crisis, whose model is booming and has spread to France.

Perhaps, today, there is a true boom in the social and cultural tradition of cooperatives, because in social networks are becoming profitable the values of the Social Economy.

\section{References}

Alburquerque Llorens, F. (2006) Clústers, territorio y desarrollo empresarial: diferentes modelos de organización productiva. Cuarto Taller de la Red de Proyectos de Integración Productiva, BID/FOMIN (San José, Costa Rica), No 1, pp. 1-14. Recuperado de http://www.sela.org.

Brazda, J., and Schediwy, R. (2003) Esbozo histórico de las cooperativas de consumo. Ciriec-España. Revista de Economía Pública, Social y Cooperativa, No 44, pp. 105136.

Cabanes Morote, M. and Gómez López, J.D. (2014) Economía social y Soberanía Alimentaria: Aportaciones de las cooperativas y asociaciones agroecológicas de producción y consumo al bienestar de los territorios. Ciriec-España. Revista de Economía Pública, Social y Cooperativa, No 82, pp. 127-154.

Calderón, B. and Calderón, M. J. (2012) La calidad del empleo de las entidades de la economía social en período de crisis. EKONOMIAZ. Revista Vasca de Economía, № 79 , Vol. 1, pp. 31-58.

Campos-Climent, V. and Sanchis Palacio, J.R. (2012) CONSUM, Sociedad Cooperativa Valenciana. Recuperado de: http://mobiroderic.uv.es/bitstream/handle/10550/29904/RIBEIRO_22CONSUM.pdf? sequence $=1 \&$ is Allowed $=y$.

Cardenete, M.A., Delgado, M.C. and Molero-Simarro, R. (2017) Costes laborales y competitividad externa de la economía andaluza (2007-2014). Revista de Estudios Andaluces, Vol. 34 (1), pp. 52-88. http://dx.doi.org/10.12795/rea.2017.i34.03.

Chaves Ávila, R. and Zimmer, A. (Eds.) (2017) El tercer sector en España y en Europa: Crisis y Resilencia, Vol. 21. Universitat de València.

10 Source: http://elpais.com/elpais/2017/03/14/alterconsumismo/1489527328_334409.html. 
Chaves Ávila, R., Monzón Campos, J.L. and Zaragoza Pascual, G. (2013) Social Economy: Concept, Macromagnitudes and Sources of Employment for the Social Work. Cuadernos de Trabajo Social, No 26, Vol. 1, pp. 19-29.

Chloupkova, J. (2002) European cooperative movement: Background and common denominators. Department of Economics and Natural Resources, Unit of Economics, The Royal Veterinary and Agricultural University.

Clemente López, J., Díaz Foncea, M. and Marcuello Servós, C. (2008) Estudio sobre las cooperativas y sociedades laborales en España: creación de empleo y contribución al desarrollo económico. Ministerio de Trabajo e Inmigración, Código F08348. Universidad de Zaragoza.

Delgado, A. et al. (2010) Cooperativismo de Consumo Emergente en Europa. Ed. Federación de Cooperativas Andaluzas de Consumidores y Usuarios (FEDECCON).

Díaz Foncea, M. and Marcuello Servós, C. (2012) Las empresas sociales en España: concepto y características. Gizarte Ekonomiaren Euskal Aldizkaria, Revista Vasca de Economía Social, № 8, pp. 143-164.

Enke, S. (1945) Consumer Co-operatives and Economic Efficiency. American Economic Review, № 35, Vol. 1, pp. 148-155.

Etxezarreta, A. and Merino, S. (2014) Las cooperativas de vivienda como alternativa al problema de la vivienda en la actual crisis económica. REVESCO. Revista de Estudios Cooperativos, Tercer Cuatrimestre, $\quad \mathrm{N}^{\mathrm{o}}$ 113, pp. 92-119. DOI: 10.5209/rev_REVE.2014.v113.43384.

Faura, I. (2002) Consumidores activos: experiencias cooperativas para el siglo XXI, 14. Icaria Editorial.

Faura, I., and Udina, T. (2004): "La actividad de las cooperativas de consumidores". Mediterráneo Económico, 6, 146-159.

Garrido Miguel, I., Salazar Terreros, I. and Vargas Montoya, P. (2017) Corporate governance model in Spanish Cooperatives. REVESCO. Revista de Estudios Cooperativos, Primer Cuatrimestre, No 123, pp. 1-20. DOI; 10.5209/REVE.53251.

Kaplan de Drimer, A. and Drimer, B. (1975) Las Cooperativas. Fundamentos-HistoriaDoctrina. INTERCOOP, Editora Cooperativa, $4^{\text {a }}$ Edición (2017).

Maixé-Altés, J.C. (2009) La modernización de la distribución alimentaria en España, 19471995. Revista de Historia Industrial, $\mathrm{N}^{\circ}$ 41, pp. 125-160.

Márquez Domínguez, J.A. (2004) Cooperativas de Consumo en Andalucía, Análisis Histórico, Identidad Geográfica y Estrategias Actuales, 97, Ed. Universidad de Huelva y Federación de Cooperativas Andaluzas de Consumidores y Usuarios (FEDECCON).

Medina-Albaladejo, F.J. and Pujol-Andreu, J. (2014) Cooperativas de consumo y niveles de vida, España (1865-1939): una primera aproximación. Revista Electrónica de Geografía y Ciencias Sociales. Vol. XVIII, 494. Recuperado de http://www.ub.edu/geocrit/sn/sn494.htm.

Ministerio de Empleo y Seguridad Social. Obtenida en junio de 2016. Disponible en: http://www.empleo.gob.es/Es/sec_trabajo/autonomos/economiasoc/EconomiaSocial/index.htm.

Monzón Campos, J.L. (2003) El cooperativismo en la historia de la literatura económica. Ciriec-España. Revista de Economía Pública, Social y Cooperativa, № 44, pp. 9-32.

Monzón Campos, J.L. (2012) Las cooperativas ante la globalización: magnitudes, actividades y tendencias". Ekonomiaz, N ${ }^{\circ}$ 79, Vol. 1, pp. 13-30.

Monzón Campos, J.L. (2016) La Economía Social en la literatura económica y en los hechos: 30 años de historia del CIRIEC-España, 1604, CIRIEC-Université de Liège. 
Monzón Campos, J.L. and Chaves Ávila, R. (2012) La Economía Social en la Unión Europea. Informe elaborado para el Comité y Social Europeo por el Centro Internacional de Investigación e Información sobre la Economía Pública, Social y Cooperativa (CIRIEC).

Pérez Ramírez, B. and Carrillo Benito, E. (2000) Desarrollo local: Manual de uso. ESIC Editorial.

Quintana, C. (2016) The power of Cooperation - Co-operatives Europe Key Figures 2015. Ed. Co-operatives Europe Public. Recuperado de https://coopseurope.coop/sites/default/files/The\%20power\%20of\%20Cooperation\%20$\% 20$ Cooperatives\%20Europe\%20key\%20statistics\%202015.pdf.

Raccanello, M. (2012) Desarrollo institucional de las organizaciones cooperativas y su literatura: el caso del cooperativismo de consumo. Revista del Centro de Estudios de Sociología del Trabajo (CESOT), № 4, pp. 1-41.

Revuelto Taboada, L. and Marche Chordá, I. (1997) De cooperativa de consumo valenciana a holding cooperativo. Análisis estratégico de la cooperativa de distribución Consum. Ciriec-España. Revista de Economía Pública, Social y Cooperativa, № 27, pp. 87-109.

Sáez, J.A. (1978) Cooperativas de consumo y economatos: su situación en el mercado a comienzos de 1976: breve análisis estadístico. Estudios Cooperativos, № 44, pp. 33-54.

Sanchis Palacio, J. and Revuelto Taboada, L. (1995) Análisis estratégico y crecimiento externo de las cooperativas de consumo españolas. Ciriec-España, Revista de Economía Pública, Social y Cooperativa, № 18 , pp. 139-167.

Vidal Martínez, I. (2012) La participación en los órganos sociales de las cooperativas de consumo en España. Revista Cooperativismo \& Desarrollo, $\mathrm{N}^{\circ} 100$, Vol. 20, pp. 194204.

Watts, D.C.H. (2017) Building an alternative economic network? Consumer cooperation in Scotland from the 1870 s to the 1960s. Economic History Review, No 70 , Vol. 1, pp. 143-170. DOI: 10.1111/ehr.12340. 